\title{
Capecitabine-induced radiation recall phenomenon: a case
}

\section{report [version 1; peer review: 1 approved, 1 approved with}

\section{reservations]}

José Aguilar, Elena García, Elisa García-Garre

Breast Unit, Morales Meseguer Hospital, SMS (Murcia's Health Service), Murcia, 30008, Spain

\author{
V1 First published: 13 Dec 2012, 1:64 \\ https://doi.org/10.12688/f1000research.1-64.v1 \\ Latest published: 07 Mar 2013, 1:64 \\ https://doi.org/10.12688/f1000research.1-64.v2
}

\begin{abstract}
Radiation recall dermatitis is defined as an inflammatory reaction of the skin at the site of previous irradiation. Different drugs have been associated with triggering this phenomenon, and it can also affect other areas and organs where previous radiotherapy has been administered. The time gap between the inflammatory reaction and previous radiation can range from days to several years.
\end{abstract}

We report what we believe to be the first case of Capecitabine-induced Radiation Therapy Oncology Group (RTOG) Grade 4 recall skin toxicity (ulcerating dermatitis), which occurred three years after skin irradiation. Clinicians should be aware of this phenomenon, even when considering patients for whom it has been a long time since previous radiation therapy. This unusual and late drug side effect should be borne in mind in the differential diagnosis and management of advanced-disease patients as it may be confused with local relapse or infectious complication of previously operated areas.

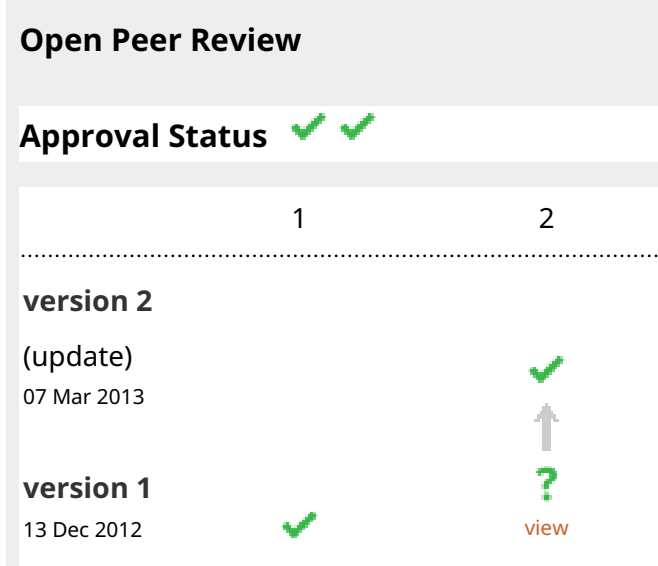

1. Jay Thomas, HealthCare Partners, Arcadia, USA

2. Rita De Sanctis, Istituto Clinico Humanitas, IRCCS, Rozzano, Italy

Any reports and responses or comments on the article can be found at the end of the article.

Corresponding author: José Aguilar (pepeaguilarjimenez@gmail.com)

Competing interests: No relevant competing interests disclosed.

Grant information: The author(s) declared that no grants were involved in supporting this work.

Copyright: @ 2012 Aguilar J et al. This is an open access article distributed under the terms of the Creative Commons Attribution License, which permits unrestricted use, distribution, and reproduction in any medium, provided the original work is properly cited. Data associated with the article are available under the terms of the Creative Commons Zero "No rights reserved" data waiver (CCO 1.0 Public domain dedication).

How to cite this article: Aguilar J, García E and García-Garre E. Capecitabine-induced radiation recall phenomenon: a case report [version 1; peer review: 1 approved, 1 approved with reservations] F1000Research 2012, 1:64

https://doi.org/10.12688/f1000research.1-64.v1

First published: 13 Dec 2012, 1:64 https://doi.org/10.12688/f1000research.1-64.v1 


\section{Introduction}

We report a case of a radiation recall phenomenon after the administration of Capecitabine, consisting of pain, hyperpigmentation, and ulceration in the field of postmastectomy irradiation (which the patient received 3 years previously).

\section{Case report}

A 78-year old woman allergic to salicylics was diagnosed with a T4dN3M0 (American Joint Committee on Cancer) infiltrating ductal left breast carcinoma (inflammatory breast cancer) in March 2006. Owing to her general condition and advanced local disease, she was initially treated with primary hormonotherapy consisting of Letrozole $2.5 \mathrm{mg} / \mathrm{d}$ over a period of 6 months with a good local response as measured by ultrasound scanning. In October 2006, she was operated on and a modified radical mastectomy was performed. Pathology reported a $6 \mathrm{~cm}$ in diameter infiltrating ductal carcinoma pT4dN2a positive for both estrogen and progesterone receptors, and Her2-neu negative. After surgery she started on chemotherapy (Taxol $80 \mathrm{mg} / \mathrm{m}^{2}$ on a weekly schedule for 4 weeks) and adjuvant radiotherapy (50 Gy over left hemithorax and supraclavicular nodes in February 2007). Immediately after initial radiotherapy, in 2007, she developed skin toxicity Radiation Therapy Oncology Group (RTOG) grade 2, which was successfully managed with topical medication (Radiocrem ${ }^{\circledR}$ Rotthafarm SL. 3 times a day). She started Letrozole $2.5 \mathrm{mg} / \mathrm{d}$ again in January 2007. In September 2009 she developed a neoplasic left pleural involvement and began hormonotherapy with Fulvestrant $500 \mathrm{mg} / \mathrm{monthly}$ for 5 months, followed by Exemestane $25 \mathrm{mg} / \mathrm{d}$ due to clinical and radiological progression. In May 2010, she developed new pleural progression, which was treated with Capecitabine at a dose of $1000 \mathrm{mg} / \mathrm{m}^{2} / 12 \mathrm{~h}$ ( 3 cycles). Three months later in July 2010, she was noted to have developed a series of ulcers on the previous mastectomy scar, which had changed in colour (hyper and dispigmentation) and elasticity (stiffness and extreme fragility) over the skin of the previously irradiated area in the left hemithorax (Figure 1). A punch-biopsy was performed and carcinoma in the involved skin was ruled out. The diagnosis of a recall radiodermitis (ulcerating dermatitis, grade 4 RTOG) was thus established in July 2010 and so Capecitabine was withdrawn and palliative $20 \mathrm{mg}$ Tamoxifen started. The skin began to improve after 3-4 weeks following withdrawal of Capecitabine and treatment with topical steroids (Menaderm® Menarini; Beclomeatsone 0.025\%). She remains on Tamoxifen treatment, and the disease is now stable.

\section{Discussion}

Radiation-recall dermatitis is an inflammatory reaction of the skin at the site of previous irradiation. Many chemotherapy drugs have been presumed to cause this phenomenon and a database to collect these rare reaction cases has even been proposed ${ }^{1}$. It can also affect other anatomical areas such as the digestive system (when abdominal radiotherapy has been used $)^{2}$. Although a closer time gap is more usual, the time gap between the inflammatory reaction and previous radiation can range from days to several years ${ }^{3}$.

There are few reported cases of Capecitabine-induced radiation recall phenomenon, the first one being authored by Ortmann et al. in $2002^{4}$.

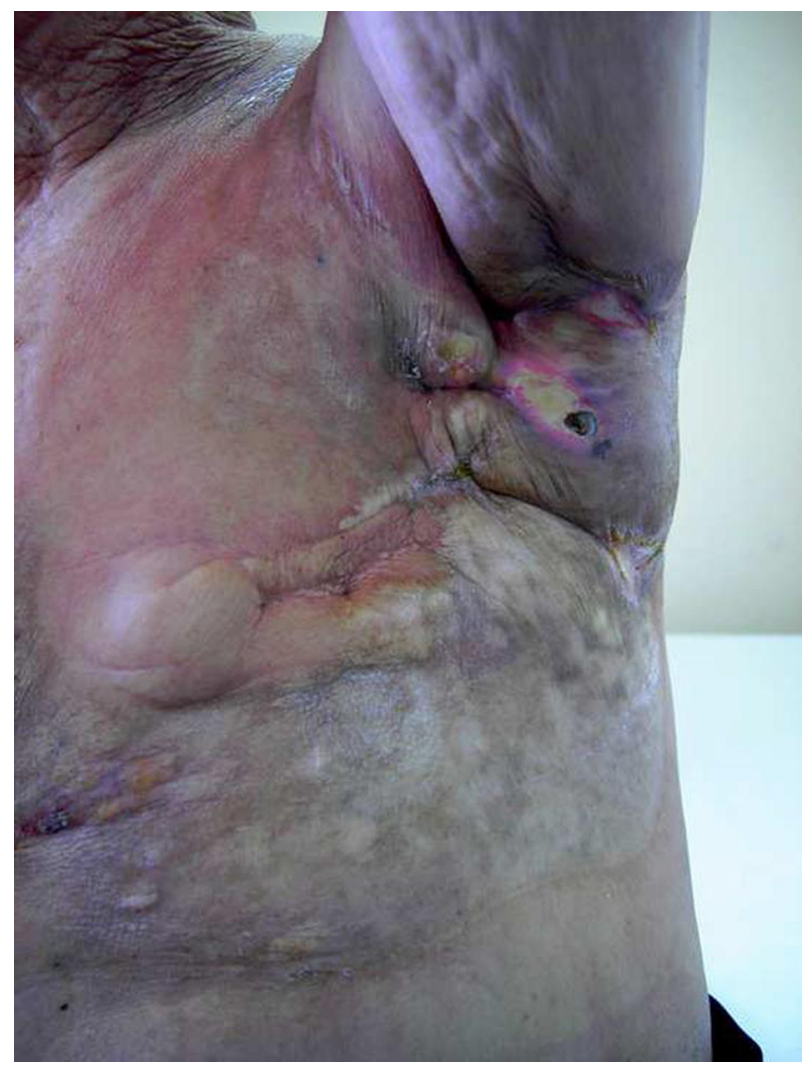

Figure 1. Recall dermatitis (RTOG grade 4): detail of ulcers.

Their hypothesis relied on the pro-drug entity of Capecitabine being capable of being activated in previously irradiated tissue.

More recently, Ghosal and Misra have reported a case ${ }^{5}$ with thoracic hyperpigmentation instead of inflammation being the main clinical finding. Other rare though well known Capecitabine side effects are hyperpigmentation associated with palmar-plantar erythrodisesthesia ${ }^{6}$ or even Stevens-Johnson syndrome ${ }^{7}$.

\section{Conclusions}

To our knowledge, this is the first reported case of Capecitabineinduced RTOG grade 4 (ulcerating dermatitis) recall skin toxicity of previously irradiated skin. We suggest it is relevant for differential diagnosis with other entities such as local cancer relapse or even surgical site infection. In case of any doubt such as in our case, punch biopsy can help. Clinicians should be aware of this phenomenon, even if a long period of time has lapsed since the previous radiation therapy.

\section{Consent}

Written informed consent for publication of the clinical details and clinical images was obtained from the patient. 
Author contributions

EG, EGG and JA were the clinicians who treated the woman reported in the case. JA prepared the first draft of the manuscript which was revised by EG and EGG. JA prepared the text. All authors have been involved in the revision of the manuscript and have agreed to the final content.
Competing interests

No relevant competing interests disclosed.

Grant information

The author(s) declared that no grants were involved in supporting this work.

\section{References}

1. Azria D, Magne $\mathrm{N}$, Zouhair $\mathrm{A}$, et al: Radiation recall: a well recognized but neglected phenomenon. Cancer Treat Rev. 2005; 31(7): $555-70$.

PubMed Abstract | Publisher Full Text

2. Saif MW, Black G, Johnson M, et al.: Radiation recall phenomenon secondary to capecitabine: possible role of thymidine phosphorylase. Cancer Chemother Pharmacol. 2006; 58(6): $771-5$.

PubMed Abstract | Publisher Full Text

3. Burris HA 3rd, Hurtig J: Radiation recall with anticancer agents. Oncologist. 2010; 15(11): 1227-37.

PubMed Abstract | Publisher Full Text | Free Full Text
4. Ortmann E, Hohenberg G: Treatment side effects. Case 1. Radiation recall phenomenon after administration of capecitabine. J Clin Oncol. 2002: 20(13): 3029-30.

PubMed Abstract

5. Ghosal N, Misra V: A case of capecitabine-induced hyperpigmentation and radiation recall phenomenon. Clin Oncol (R Coll Radiol). 2009; 21(8): 632. PubMed Abstract | Publisher Full Text

6. Pui JC, Meehan S, Moskovits T: Capecitabine induced cutaneous hyperpigmentation: report of a case. J Drug Dermatol. 2002; 1(2): 202-205. PubMed Abstract

7. Sendur M, Kilickap S: Stevens-Johnson síndrome after treatment with capecitabine. Clin Oncol (R Coll Radiol). 2008; 20(2): 202-203. PubMed Abstract | Publisher Full Text 


\section{Open Peer Review}

\section{Current Peer Review Status:}

\section{Version 1}

Reviewer Report 19 December 2012

https://doi.org/10.5256/f1000research.233.r398

(C) 2012 De Sanctis R. This is an open access peer review report distributed under the terms of the Creative Commons Attribution License, which permits unrestricted use, distribution, and reproduction in any medium, provided the original work is properly cited.

\section{Rita De Sanctis}

Humanitas Cancer Center, Istituto Clinico Humanitas, IRCCS, Rozzano, Italy

I give this article an 'approved with reservations'. The reason for this is that I found that it lacks a few fundamental aspects:

What was the response after 3 cycles of capecitabine? Please remember (and eventually cite) some reports of skin toxicity as predictor of response.

It would be interesting to provide a description of the inflammatory characteristics of the punch-biopsy (even with iconografic report, if available).

What was the presentation of the skin toxicity? Sudden or progressive? Were some topical medications used before the appearance of Figure 1 aspects?

"Palliative" is all the setting of the present clinical case and not only when the authors decided to withdrawn capecitabine. What is the reason for the choice of tamoxifen instead of another chemotherapy,i.e. vinorelbine?

Radiocrem (R): please provide the active components and avoid the commercial brand. What was the duration of stable disease ("the disease is now stable").

Palmar-plantar erythrodisesthesia is not so rare with capecitabine (my group and I have reported a $8 \%$ of G3/G4 skin toxicity with capecitabine). Moreover, according to guidelines of side effects management, do the authors believe that a rechallenge with capecitabine after dose reduction could be performed?

Competing Interests: No competing interests were disclosed.

I confirm that I have read this submission and believe that I have an appropriate level of expertise to confirm that it is of an acceptable scientific standard, however I have significant reservations, as outlined above.

Author Response 08 Feb 2013

Jose Aguilar, Morales Meseguer Hospital, SMS (Murcia's Health Service), Murcia, Spain 
Dear Dr De Sanctis, Thank you for your detailed and relevant comments. We have sent an amended text to the editor that includes the following answers to your questions (and 2 figures from the skin biopsy):

1) After 3 cycles of capecitabine, the disease remained stable. Some authors have suggested that skin toxicity might be a predictor of response, though it has been better related to antiepidermal growth factor receptor monoclonal antibodies (Petrelli F, et al. The predictive role of skin rash with cetuximab and panitumumab in colorectal cancer patients: a systematic review and meta-analysis of published trials. Target Oncol. 2013 Jan 16. [Epub ahead of print] ) http://www.ncbi.nlm.nih.gov/pubmed/23321777

2) In the biopsy, ulcers can be easily seen over granulation tissue. The area with preserved epidermis shows acanthosis and parakeratosis with loss of epidermal ridges. Vascular ectasia, hyalinized collagen and loss of skin adnexa is seen in the dermis. Infiltration by neoplasm was ruled out. We have enclosed 2 new figures with these findings to the original text. You can view these in Version 2 of our article, Figure 2.

3) Skin toxicity appeared in a rapidly progressive pattern, no more than 2 weeks after the patient felt the first symptoms (skin stiffness and a burning local sensation). No topical medication was used before the skin rash appeared.

4) The term "palliative" has been used throughout the text to describe chemotherapy in the context of a patient with metastatic disease, with the objective of relieving symptoms and to delay the expected evolution. The possibility of the ulcers being the origin of an opportunistic infection was the reason why we chose the option of tamoxifen treatment instead of further chemotherapy.

5) Radiocrem ${ }^{\circledR}$ was used to avoid description of the different active components of the cream that include: tocopheryl acetate, disodium EDTA, Silybum marianum, Vitis vinifera, etc.

6) Tamoxifen treatment allowed the patient to have 4 months with stable disease and serologic response. Afterwards, pleural progression was diagnosed and vinorebiline treatment was started with a good response; after 8 cycles, the patient suffered a new episode of skin toxicity that was managed with vinorebiline withdrawal and Letrozole treatment, which allowed for a 9 month stability period. On March 2012, progression was seen (liver metastasis and greater pleural effusion with clinical deterioration) and cyclophosphamide treatment was started. All active medication was stopped in May and palliative care lasted until the patient died a few months afterwards.

7) We agree with your statement. "Rare" might not be the best word for this side effect frequency. Anyway, though palmar-plantar erythrodisesthesia is a well known dosedependent effect, recall radiodermatitis does not seem to have that characteristic. That is why we tried to find another treatment and did not use capecitabine again in this patient.

Competing Interests: No competing interests are declared. 
(C) 2012 Thomas J. This is an open access peer review report distributed under the terms of the Creative Commons Attribution License, which permits unrestricted use, distribution, and reproduction in any medium, provided the original work is properly cited.

\section{Jay Thomas}

Comprehensive Care Program, HealthCare Partners, Arcadia, USA

Competing Interests: No competing interests were disclosed.

I confirm that I have read this submission and believe that I have an appropriate level of expertise to confirm that it is of an acceptable scientific standard.

The benefits of publishing with F1000Research:

- Your article is published within days, with no editorial bias

- You can publish traditional articles, null/negative results, case reports, data notes and more

- The peer review process is transparent and collaborative

- Your article is indexed in PubMed after passing peer review

- Dedicated customer support at every stage

For pre-submission enquiries, contact research@f1000.com 